\title{
Peacekeeping after Covid-19
}

Han Dorussen (University of Essex)

hdorus@essex.ac.uk

Submitted to Peace Economics, Peace Science and Public Policy

Originally: 18 May 2020; Revised version: 6 June 2020

\begin{abstract}
The 2020 Covid-19 pandemic may not be a game changer for future peacekeeping and humanitarian operations, but it is likely to strengthen developments that have been on-going since the early 2010s. Since then, major global and regional powers have increasingly pursued self-interested policies, interventions have become less accepted by host countries, and the UN is more financially constrained. These developments all point towards fewer and smaller interventions. Responses to Covid-19 so far suggest these trends to continue. Arguably, this hampers effective and collaborative action against global challenges such as Covid-19.
\end{abstract}

\section{Introduction}

Covid-19 already has had an enormous impact endangering the lives and livelihoods of many people around the world. Especially for people caught up in conflict and often living in cramped and unsanitary conditions in refugee sites, Covid-19 poses enormous risks. Will the Covid-19 pandemic also decisively alter peacekeeping, peacebuilding and even more generally humanitarian engagement? Will it provide a fatal blow for Peaceland ${ }^{1}$ or will it re-energize the international community to support the most vulnerable? It is indeed tempting to identify 2020 as a breakpoint with notably less political and humanitarian engagement and peacekeeping in the wake of the Covid-19 pandemic. However, I will argue that the reversal already took place prior to 2020. The NATO intervention in Libya in 2011, the Russian intervention in the Ukraine and Syria in 2015, and the 2016 election of Trump as US president were all more important moments in the decline of UN peacekeeping and -building. The Covid-19 pandemic is prone to strengthen these developments and, if as expected the pandemic eventually strikes across Latin America, Africa and Asia, a lackluster multilateral response will aggravate its impact.

The end of the Cold War not only marked an expansion in peacekeeping and peacebuilding interventions, but also changed their nature: peacekeepers were deployed to civil wars and humanitarian emergencies with robust protection of civilians as a central element of their 
mandates. Whereas initially there was little change in the main contributors, mainly European and South-Asian countries, over time the group of contributing countries expanded considerably with regional countries replacing European ones and China emerging as a significant contributor. Although the failures and shortcomings of peacekeeping have been documented extensively (Paris 2004; Autesserre 2010; 2014), there is an emerging consensus that peacekeeping has supported peace agreements and contributed to reducing violence (Fortna 2008; Hultman, Kathman and Shannon 2013; Dorussen 2014; Ruggeri, Dorussen and Gizelis 2017). All in all, the ledger seems to be positive, but notwithstanding its achievements, peacekeeping appears to have hit rough times.

The remainder highlights three main challenges and discusses how the limited global response to the Covid-19 crisis illustrates their gravity. First of all, powerful political leaders increasingly view problems from a nationalist perspective and have become unwilling or unable to collaborate. Secondly, there is not only a reluctance to act, but host countries increasingly distrust interventions and see them as attacks on national autonomy. Finally, UN agencies lack resources to maintain large-scale interventions and are looking for cheaper alternatives. So far, Covid-19 seems to strengthen these trends rather than to lead to a recognition that things could be handled better differently. I consider the future of peacekeeping and humanitarian interventions in light of my own evaluations of previous interventions, in particular, the UN peacekeeping missions to Timor-Leste and Haiti. In these countries, the UN responded decisively - although definitely with important failings - to unfolding humanitarian crises as the result of conflict and natural disasters. How feasible will it be for the UN to respond similarly in the future?

\section{Every man for himself and the Devil take the hindmost}

The consensus among the main powers, that they share a collective responsibility to maintain global peace and stability, has broken down step-by-step since 2010. Conflicts are once again viewed through the lens of global political competition with the main powers, in particular the USA and Russia, regularly backing opposing factions. Rather than supporting multinational peacekeeping operations, countries prefer to intervene militarily, either directly or via proxies, and aim to change the situation on the ground by forcing a military solution. It is easy to find examples, such as the USA, UK and France intervening in Libya in 2011, Russia and Turkey in Syria since 2015 and in Libya in 2020. In contrast, peacekeeping generally aims at stabilizing stalemated conflicts in order to create space for a political solution. Even countries that remain 
more committed to multilateralism, like the UK, France and other EU member states, often deploy their forces alongside UN peacekeeping missions rather than taking part in them; e.g., the French operations Serval in Mali and Sangaris in the Central African Republic (CAR) (Howard 2019). Regional 'hegemons' like Ethiopia and Rwanda have become major contributors to UN peacekeeping in Africa $^{2}$, while the contributions of China to these missions reflect its increased political and economic interests in Africa.

The willingness of the UN to mandate new peacekeeping missions has decreased markedly. Between 2001 and 2010, 11 new missions were mandated, but since then only six. The last large missions in South Sudan, Mali, and the CAR started in 2011, 2013 and 2014 respectively. Between December 2015 and 2020, the number of peacekeepers deployed decreased from 107,088 to 83,331 ; a decline of $22 \%$. The UN has also closed a number of large ambitious missions; e.g., Timor-Leste in 2012, Haiti and Côte d'Ivoire in 2017, and Liberia in 2018. The declining support for multilateralism also shows in the more limited goals of recent missions. ${ }^{3}$ There is no longer a consensus around liberal peacekeeping - where admittedly this consensus was always rather minimal and skin deep - and peacekeeping is now mainly pursued to avoid humanitarian disasters, to counter the threat of (jihadist) terrorism, or to secure regional influence. On-going peacekeeping missions in Mali, CAR, South Sudan, Democratic Republic of the Congo (DRC), and Somalia are all motivated by such concerns rather than to support the development of democratic, rule-of-law based governance.

So far, the response to the Covid-19 pandemic does not suggest a change of hearts. In particular, US president Trump has questioned the usefulness of a global multilateral response and instead attacked the World Health Organization (WHO) for mishandling the pandemic and accused it of bowing to Chinese political pressure. China strongly denies these accusations, but at the same time failed to cooperate fully and politicized the role of the WHO in Taiwan. Calls of the UN Secretary General, António Guterres, for a global ceasefire to allow for humanitarian access to facilitate Covid-19 responses, have been largely ignored, with progress on a Security Council resolution blocked by the USA. ${ }^{4}$ Conflicts in Yemen, Libya and Syria have continued unabated in 2020 without realistic prospects for peace agreements and possible UN peacekeeping missions. In Syria, during the Covid-19 pandemic, Russia blocked UN relief agencies to fund NGOs that were delivering health services across the Iraqi border to rebel held areas in Syria. 5 


\section{The 'Republic of NGOs' ${ }^{6}$}

The reluctance of the UN Security Council to mandate new peacekeeping missions is matched by a reduced willingness of countries to host such missions. Fortna (2008) observes that the UN rarely refuses to deploy when a member state asks for a mission to be sent to its territory. Host country consent, however, requires that governments and armed factions engage in meaningful negotiations to reach a power-sharing agreement and agree it to be backed up by a peacekeeping mission. Yet power-sharing arrangements can be fragile; for example, in South Sudan, clashes between factions led by Kiir and Machar also targeted peacekeepers, leading the UN to change the mandate of its mission from peace- and state-building towards the protection of civilians, human rights monitoring and support for the delivery of humanitarian assistance. ${ }^{7}$ Instead of negotiating, Syrian President Bashar al-Assad relies on Russia to block any meaningful UN intervention and to provide direct military support allowing him to hold out for military victory. In Africa, political leaders are increasingly openly critical of interventions by the $\mathrm{UN}$ or even regional organizations and argue that they undermine national sovereignty; e.g., Weah in Liberia or Embaló in Guinea Bissau. UN interventions are now commonly portrayed as a form of neo-imperialism imposing Western neoliberal values and standards discriminatorily on African leaders. In 2019, the Burundi government relied exactly on such arguments to justify closing the UN Human Rights Office.

Not only politicians, but also the general public has become less willing to accept peacekeeping missions and other interventions, in part because repeated incidences of sexual (and other forms of) abuse have undermined their legitimacy. In a survey that I implemented in 2013 after the completion of the UN peacekeeping mission in Timor-Leste, $74 \%$ of the respondents agreed with the statement that the UN missions should have ended earlier, while nearly $70 \%$ were happy that the UN peacekeepers had left because the mission had many problems. At the same time, nearly everybody (96\%) agreed that they were 'grateful to the UN' (Dorussen 2015).

In Haiti, the UN peacekeeping mission and international nongovernmental organizations (INGOs) have become especially contested. UN peacekeepers were responsible for spreading cholera leading to at least 9,000 deaths and up to 800,000 Haitians infected, and the initial reluctance of the UN to accept responsibility and compensate victims made matters even worse (Katz 2013). In 2018, aid workers were accused of sexual abuse and their employer (Oxfam) of trying to hide the events. ${ }^{8}$ In our 2019 survey of a representative sample of nearly 2000 Haitians, we find indeed very low levels of trust in foreign organizations (Bakaki and Dorussen 
2020). Nearly $75 \%$ of the respondents describe the UN as corrupt and $70 \%$ as arrogant. INGOs are seen as arrogant and/or corrupt by nearly $70 \%$ as well. Only about $6 \%$ describes the UN or INGOs as trustworthy.

Concerns about the risks of spreading infectious diseases posed by peacekeepers and other outsiders are widespread. The cholera epidemic in Haiti has shown how real these risks can be, and understandably led to protests that occasionally turned violent. ${ }^{9}$ Yet even without clear reason, suspicions can lead to hostility against peacekeepers and aid works as shown in the Ebola epidemic in the DRC; Medecins Sans Frontieres (MSF) reported 300 attacks against Ebola health workers in 2019. ${ }^{10}$ Increased hostility towards UN peacekeepers has motivated some INGOs to distance themselves from peacekeeping operations (Dorussen and de Vooght 2018). Recognizing that Covid-19 may further hamper UN peacekeeping, UN Secretary General Guterres has emphasized its contributions to handling the pandemic:

Our peacekeeping operations and special political missions will continue to be guided by four key objectives: First, to support national authorities in their response to COVID-19. Second, to protect our personnel and their capacity to continue critical operations. Third, to ensure that our own personnel are not a contagion vector. And fourth, to help protect vulnerable communities and continue to implement mission mandates. (UN Secretary General Guterres, 20 April 2020) ${ }^{11}$

It is still too early to tell whether the UN will be able to meet these key objectives or whether Covid-19 will undermine the ability of the UN to continue its missions. An example of possible problems ahead is the decision of the government of Burundi to expel four WHO representatives presumably in response to their warnings against holding elections during the Covid-19 pandemic. $^{12}$

\section{Getting by on a Shoestring}

Finally, the UN is increasingly financially constrained and finds it hard to finance the current number of peacekeeping missions and peacekeepers deployed. Given that the US is the largest financial contributor to the UN, the skepticism of the Trump administration to fund UN initiatives has a real impact on the UN budget. The Action for Peacekeeping (A4P) declaration emphasizes that member states should provide sufficient resources in line with the mandates 
of UN peacekeeping operations. ${ }^{13}$ The UN has identified savings to its peacekeeping budget; in part by closing down a number of its peacekeeping missions. In Liberia, Côte d'Ivoire, and Haiti, peacekeeping missions have been replaced with smaller civilian-led political missions. The A4P program also emphasizes the importance of political solutions and political support of the member states for on-going missions.

The increasing importance of political missions clearly precedes the Covid-19 pandemic. In our research, we have found that the number of UN diplomatic initiatives, including political missions and good offices engagement, has exceeded the number of UN peacekeeping missions since 2005 (see Figure 1). Moreover, the number of political missions has been increasing rapidly while the number of peacekeeping missions has decreased since 2015 (Dorussen and Clayton 2018, Clayton, Dorussen, and Böhmelt 2020). In 2020, there are 14 peacekeeping missions and 25 political missions. ${ }^{14}$ Political missions are important because they allow the UN to mediate political solutions to armed conflicts, e.g., in Yemen, Syria, Somalia and Libya, and to contribute to peacebuilding; e.g., in Haiti and Colombia. At the same time, they lack the reach and scope of the large multidimensional and integrated peacekeeping missions the UN once deployed to Timor-Leste and continues to deploy to the DRC. Multidimensional missions can play an important role in dealing with looming health or humanitarian crises because of Covid-19, whereas the options of - the much smaller - political missions will be much more limited.

[Figure 1 about here]

If anything, Covid-19 will further limit the resources available to the UN. Dealing with the immediate healthcare and economic costs of the crisis is already burdening the finances of governments (and individuals) around the world. Financing the recovery from Covid-19 will be extraordinarily expensive. Even though foreign aid and contributions to the UN are minor expenditures in government budgets, they may well become targets of cost-savings. This is particularly likely when support of UN agencies gets politicized, as illustrated by the decision of the Trump administration to terminate US membership of the WHO.

\section{Conclusions}

Covid-19 is still spreading around the world with increasingly serious humanitarian and economic consequences with the ultimate impact of the crisis as yet unknown. Initially, Covid19 mainly affected China and developed economies in Asia, Europe and North America. It is still unclear how serious the consequences will be for countries in Latin America, Africa and 
South and Southeast Asia, and for obvious reasons there are real concerns about their ability to cope with the fallout of the pandemic.

Already for a number of years, the UN has been unable to initiate large multidimensional peacekeeping missions while it reduced the scope of on-going missions. The necessary political will to support such missions in the Security Council no longer exists. Political leaders and the general population in (potential) host countries seem increasingly distrustful of foreign interventions. Finally, the UN has to deal with tight financial constraints motivating it to end or down-size missions whenever possible. Compared to the total amount of global military expenditures (estimated at $\$ 1,747$ billion in 2013), the UN budget for peacekeeping (\$6.51 billion in 2019-2020) ${ }^{15}$ is very small indeed. Yet, it still allows the UN to support political agreements, protect civilians and secure the provision of humanitarian aid. The situation of civilians in conflict zones around the world remains extremely precarious; they risk getting caught up in military confrontations and are often under direct threat from rebel factions as well as government forces. Refugees and internally displaced people are often only marginally more secure. Now all of them also have to deal with the possibility of Covid-19 spreading across conflict-affected communities and refugee sites. The expected impact of Covid-19 on the most vulnerable justifies large-scale international support, where necessary backed up by a sufficiently resourced peacekeeping operation. The response to the earthquake in Haiti in 2010 or the spread of Ebola in West Africa in 2013 demonstrates that international support and peacekeepers can make a difference, at least in dealing with the immediate aftermath of a crisis. Admittedly it is much less clear how to deal best with political crises and instability in the longer run but hoping that problems will sort themselves out seems little more than wishful thinking.

\section{References}

Allen, Susan Hannah, and Amy T. Yuen. 2020. "Action or inaction: United Nations Security Council activity, 1994 - 2013.” Journal of Peace Research, first view. https://doi.org/10.1177/0022343319900222

Autesserre, Séverine. 2010. The Trouble with the Congo; Local Violence and the Failure of International Peacebuilding. Cambridge: Cambridge University Press. Autesserre, Séverine. 2014. Peaceland. Conflict Resolution and Everyday Politics of International Interventions. New York: Cambridge University Press 
Bakaki, Zorzeta, and Han Dorussen. 2020. Shades of ‘blan'? Fielding a survey on political trust in Haiti. Typescript University of Essex.

Clayton, Govinda, Han Dorussen, and Tobias Böhmelt. 2020. "United Nations Peace Initiatives 1946-2015: Introducing a New Dataset.” International Interactions

Dorussen, Han. 2014. “Peacekeeping Works, or Does It?” Peace Economics, Peace Science and Public Policy 20 (4): 527-538, doi: 10.1515/peps-2014-0039.

Dorussen, Han. 2015. "Security Perception after the Completion of UN Peacekeeping in Timor-Leste." Peace Economics, Peace Science and Public Policy 21 (4): 453-458, doi: 10.1515/peps-2015-0023.

Dorussen, Han, and Govinda Clayton. 2018. "Political Initiatives and Peacekeeping: Assessing Multiple UN Conflict Resolution Tools.” Peace Economics, Peace Science and Public Policy 24 (4), doi: https://doi.org/10.1515/peps-2018-0026.

Dorussen, Han and Marian de Vooght. 2018. Putting Civilians First: NGO perceptions and expectations of UN peacekeeping. Folke Bernadotte Academy, Policy Brief 01/2018. https://fba.se/en/about-fba/publications/putting-civilians-first-ngo-perceptions-andexpectations-of-un-peacekeeping/. Accessed 18 May 2020.

Fortna, Virginia P. 2008. Does Peacekeeping Work? Shaping Belligerents' Choices after Civil War. Princeton: Princeton University Press.

Howard, Lise Morjé. 2019. Power in Peacekeeping. Cambridge: Cambridge University Press. Hultman, Lisa, Jacob Kathman, and Megan Shannon. 2013. "United Nations Peacekeeping and Civilian Protection in Civil War.” American Journal of Political Science, 57 (4): 875 891.

Katz, Jonathan. 2013. The Big Truck. How the World Came to Save Haiti and Left a Disaster Behind. New York: Palgrave Macmillan

Paris, Roland. 2004. At War's End: Building Peace after Civil Conflict. Cambridge University Press, Cambridge.

Ruggeri, Dorussen and Theodora-Ismene Gizelis. 2017. "Winning the Peace Locally: UN Peacekeeping and Local Conflict.” International Organization 71 (1): 163 - 185. 


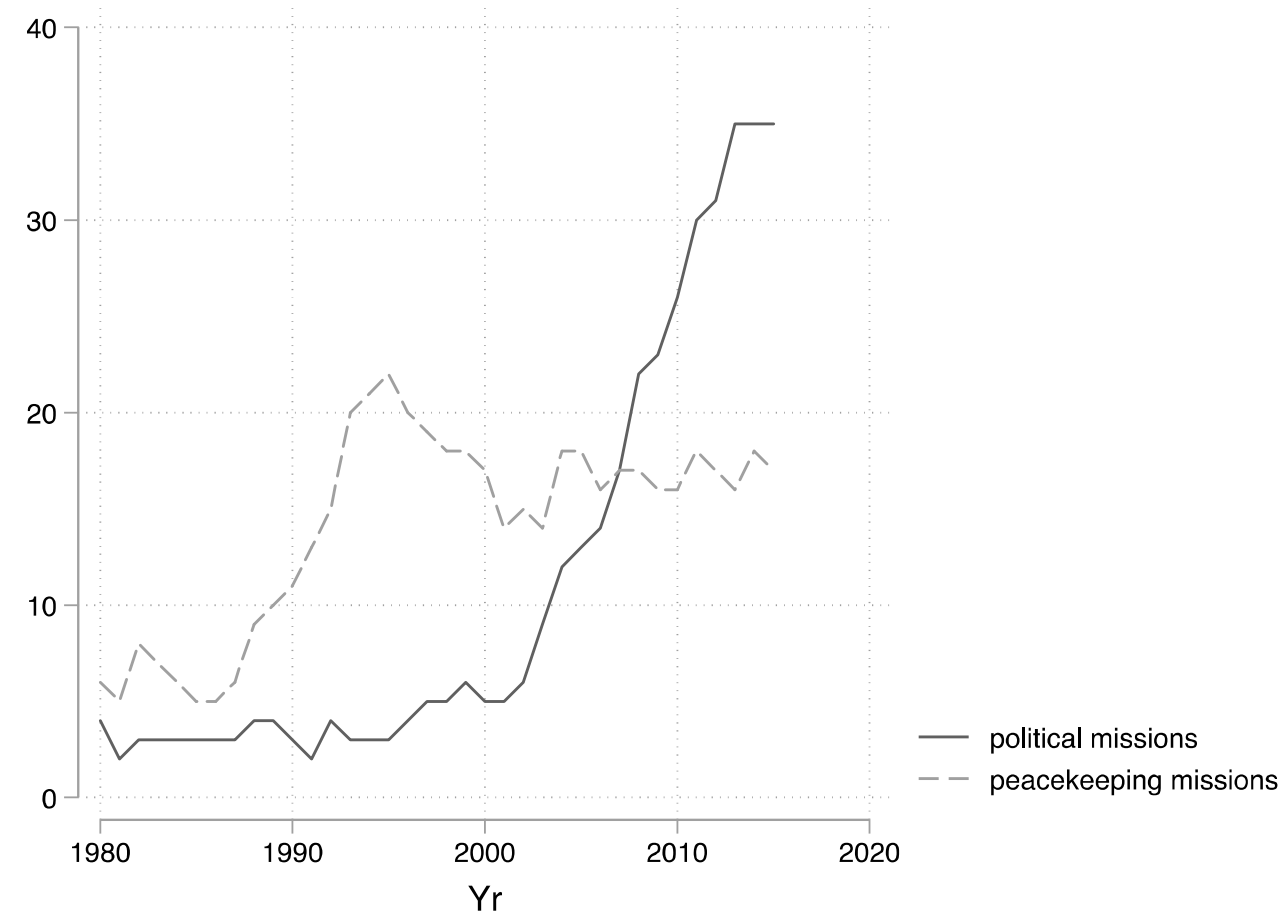

Figure 1 United Nations Political and Peacekeeping Missions, 1980 - 2016 
${ }^{1}$ Autesserre (2014) uses Peaceland to describe the community of foreign organizations, such as the UN and NGOs, engaged in peacekeeping and peacebuilding.

${ }^{2}$ Based on data from March 2020, https://peacekeeping.un.org/en/troop-and-policecontributors. Accessed 16 May 2020.

${ }^{3}$ Allen and Yuen (2020) already report a drop of informal consultations in the UN Security Council in the early 2000s which are somewhat offset by increased formal meeting. Between 1985 and 2015, the number of total resolutions annually remained very stable. This seems to fit the shift from a collaborative to a more 'business-like' atmosphere.

${ }^{4}$ The Guardian (8 May 2020) "US blocks vote on UN's bid for global ceasefire over reference to WHO“, https://www.theguardian.com/world/2020/may/08/un-ceasefireresolution-us-blocks-who, accessed 12 May 2020.

${ }^{5}$ Foreign Policy (Colum Lynch), 'Bowing to Russia, UN Halts Funding for Pandemic Relief in Northeastern Syria', 13 May 2020: https://foreignpolicy.com/2020/05/13/coronaviruspandemic-syria-russia-united-nations-relief-agencies/. Accessed 14 May 2020.

${ }^{6}$ Katz (2013) characterizes Haiti in the wake of the devastating earthquake in 2010 as a 'Republic of NGOs'.

${ }^{7}$ UN resolution 2155 (27 May 2014): https://unmiss.unmissions.org/background. Accessed 14 May 2020.

${ }^{8}$ BBC News, 11 June 2019: https://www.bbc.co.uk/news/uk-48593401. Accessed 16 May 2020

${ }^{9}$ The Guardian, 16 November 2010:

https://www.theguardian.com/world/2010/nov/16/protestors-haiti-un-peacekeepers-cholera. Accessed 17 May 2020. AP News, 22 June 2017:

https://apnews.com/b1c85223e66a4b2bb10b75ac971191a2/UN-Security-Council-lands-inHaiti-to-protests-over-cholera). Accessed 17 May 2020.

${ }^{10}$ Médecins Sans Frontieres. DRC Ebola outbreaks, Crisis Update April 2020: https://www.msf.org/drc-ebola-outbreak-crisis-update. Accessed 17 May 2020. The Guardian, 27 November 2019: https://www.theguardian.com/globaldevelopment/2019/nov/27/ebola-staff-in-congo-on-lockdown-after-angry-residents-storm-uncamp. Accessed 17 May 2020. 
${ }^{11}$ United Nations Peacekeeping, 10 April 2020: https://peacekeeping.un.org/en/unsgsremarks-to-security-council-covid-19-pandemic. Accessed 17 May 2020

${ }^{12}$ BBC News, 14 May 2020: https://www.bbc.co.uk/news/live/world-africa-47639452. Accessed 14 May 2020

${ }^{13}$ UN Action for Peacekeeping: https://peacekeeping.un.org/sites/default/files/a4pdeclaration-en.pdf. Accessed 17 May 2020.

${ }^{14}$ United Nations Peace Operations: https://www.unmissions.org. Accessed 17 May 2020.

${ }^{15}$ Based on UN information: https://peacekeeping.un.org/en/how-we-are-funded. Accessed 18 May 2020 